\title{
Spontaneous Mammary Carcinomas in Female Dogs: Association between the Immunohistochemical Degree of Aggressiveness of Tumors, Intensity of DNA Damage and Residues of Pyrethroids*
}

\author{
Yara de Oliveira Brandão ${ }^{1 \#}$, Marcia Moleta Colodel $^{1}$, Glenda Nicioli da Silva ${ }^{2}$, \\ Stephane Cássia Vexenat ${ }^{1}$, Isabelle Ferreira ${ }^{3}$, Yamê Fabres Robaina Sancler da Silva ${ }^{4}$, \\ Camilo Bulla ${ }^{5}$, Noeme Sousa Rocha ${ }^{1}$
}

\begin{abstract}
${ }^{1}$ Department of Clinical Veterinary Medicine, Laboratory of Investigative and Comparative Pathology, School of Veterinary Medicine and Animal Science, São Paulo State University, Botucatu, Brazil; ${ }^{2}$ Departamentof Pathology, School of Medicine, São Paulo State University, Botucatu, Brazil; ${ }^{3}$ Laboratory of Biomedical Vibrational Spectroscopy (LEVB), Institute of Research and Development, Universidade do Vale do Paraíba, Urbanova, Brazil; ${ }^{4}$ Department of Reproduction, São Paulo State University, Botucatu, Brazil; ${ }^{5}$ Department of Pathobiology and Population Medicine, College of Veterinary Medicine, Mississippi State University, Starkville, USA.
\end{abstract}

Email: \#yara_brandao@hotmail.com

Received May $3^{\text {rd }}, 2013$; revised June $5^{\text {th }}, 2013$; accepted June $27^{\text {th }}, 2013$

Copyright (C) 2013 Yara de Oliveira Brandão et al. This is an open access article distributed under the Creative Commons Attribution License, which permits unrestricted use, distribution, and reproduction in any medium, provided the original work is properly cited.

\begin{abstract}
Diagnosis and biological behavior of breast cancer of female dog represent one of the biggest challenges facing the Veterinarian in recent years. Due to its exponential growth and the degree of aggressiveness, the exact cause of this tumor is probably multifactorial and it is believed that may suffer influence from environmental factors. Among the suspected environmental contaminants are the pyrethroids. Aiming to investigate the participation of pyrethroids in tumorigenesis in female dogs, a study was conducted using 50 female dogs, 22 were positive for simple breast carcinoma (Group I), 18 with a diagnosis of complex breast carcinoma (Group II) and 10 negative (Group III) for breast cancer. In order to detect DNA damage, the Comet assay was performed on mammary samples of these animals, which also had samples submitted to the technique of High Performance Liquid Chromatography (HPLC), which aimed to quantify the concentration of pyrethroids. The results of HPLC of each animal were compared with those obtained by the Comet assay analysis of variance and the means were compared by the test groups "Student $\mathrm{T}$ " at the significance level of $\mathrm{p} \leq$ 0.05. Despite presenting correlation between the amount of DNA damage and tumor aggressiveness, no statistical differences were found in the DNA damage of different histologic types of breast carcinoma. As for pyrethroids, even these were detected in $22 \%$ of tumor tissues and peritumoral fat, there was no difference in DNA damage between cells exposed and not exposed to environmental contaminant.
\end{abstract}

Keywords: Mammary; Carcinomas; DNA Damage; Pyrethroids

\section{Introduction}

Mammary neoplasia is a disease of multifactorial etiopathogeny that suffers influence by intrinsic and by external factors to the organism, among which are environmental contaminants $[1,2]$. A group of these contaminants, the pyrethroids, is widely used as an insecticide and pesticide in agriculture, livestock and domestic ani-

\footnotetext{
"Conflict of interest: The authors declare no conflicts of interest. Acknowledgments institutions: FAPESP, Cnpq, PIBIC.

"Corresponding author.
}

mals, and they are absorbed, metabolized, excreted and accumulated by man and other animals mainly in adipose tissue because of its lipophilicity $[3,4]$.

By having characteristics liposoluble, pyrethroids cross lipid membranes and cause damage to exposed cells $[5,6]$, which can then lead to neoplastic development. Despite having such characteristics, the International Agency for Research on Cancer (IARC) considers that there is no evidence of carcinogenicity of pyrethroids, in particular deltamethrin, in animals experimentally exposed to them, 
and thus it were classified in Group III risk, not as a carcinogen reliable [7].

The genotoxicity was detected by Comet Assay in human nasal mucosa cells and lymphocytes of mice Winstar, and the DNA damage was higher in cells exposed to a lesser amount of pyrethroid for more time than the exposed for less time to a greater amount of the contaminant. This fact probably resulting from its lipophilic character slows diffusion cell of that compound [8-10]. Were still observed chromosomal aberrations and micronucleus formation induced by deltamethrin in human lymphocytes and bone marrow cells of mice [11].

In order to extrapolate these results to the scope of Veterinary Medicine, our research group has standardized the technique of high performance liquid chromatography-HPLC for the detection of residues of allethrin, cyhalothrin, cypermethrin, deltamethrin and tetramethrin in adipose tissue of female dogs, finding a contamination level of $40 \%$ [3]. In this context, this study aims to investigate possible influences of environmental contaminant by pyrethroid in chemical carcinogenesis, especially with regard to DNA damage of epithelial cancer breast cells of the female dog.

\section{Material and Methods}

This study is in accordance with the Ethical Principles in Animal Experimentation and was approved by the Ethics Committee of FMVZ/UNESP/Botucatu/SP, under protocol number 42/2009. The inclusion of animals was subject to owners consent by signing a consent form, after clarification of the experimental protocol.

This study is in accordance with the Ethical Principles in Animal Experimentation and was approved by the Ethics Committee of FMVZ/UNESP/Botucatu/SP, under protocol number $42 / 2009$. The inclusion of animals was subject to owners consent by signing a consent form, after clarification of the experimental protocol.

For the present study were used 50 female dogs treated at the Veterinary Hospital of UNESP, Botucatu, São Paulo, Brazil, with no predilection for race and age between seven and 12 years. The animals were randomly divided into three groups, with Groups I $(\mathrm{n}=22)$ and II $(\mathrm{n}=18)$ comprised of female dogs, who had breast cancer diagnosed by histopathology and classified as simple and complex squamous carcinoma, respectively. Group III (control) $(\mathrm{n}=10)$ consisted of female dogs that had clinical and histopathological diagnosis negative for malignancy in breast cancer. The samples of Group I and Groups II and III were obtained during the procedure of mastectomy and an elective ovary histerectomy respectively.

For toxicological analysis were harvested $5 \mathrm{~g}$ of neo- plastic tissue (Groups I and II) and $5 \mathrm{~g}$ normal breast inguinal (Group III). Were also collected from all dogs, $5 \mathrm{~g}$ of breast adipose tissue adjacent the incision. The fragments obtained were kept under refrigeration at a temperature of $-4^{\circ} \mathrm{C}$ until analysis toxicological performed by High Performance Liquid Chromatography (HighPerformance Liquid Chromatography (HPLC)) according to the method described by [12] adapted for the quantitative determination of the concentrations pyrethroid residues in samples of adipose tissue and breast. Both tissues selected from 50 bitches were processed for extraction of active ingredients allethrin, cypermethrin, deltamethrin and tetramethrin.

Detection of DNA damage was performed using the Comet Assay performed on cells harvested by citopuncture of mammary tumors surgically excised (Groups I and II) and 11 fragments of biopsied breast of animals in Group III. The test was conducted in accordance with the methodologies previously described [13] with modifications and all steps were performed under indirect light. After harvesting the cells of the breast tissue, they were suspended in PBS free of $\mathrm{Ca}^{2+}$ and $\mathrm{Mg}^{2+}$ in cold and in the dark, the sample was homogenized and $7.5 \mu 1$ of suspension were mixed with $100 \mu \mathrm{l}$ of agarose of low melting point $(0.5 \%)$. The sample was mixed and gently stretched on a glass slide pre-coated with standard agarose, covered with a coverslip and kept at $4^{\circ} \mathrm{C}$ for five minutes to solidify.

After this period, the coverslips were gently removed and the cells were lysed by immersion in cold lysis solution $(2.5 \mathrm{M} \mathrm{NaCl}, 100 \mathrm{mM}$ EDTA, $10 \mathrm{mM}$ Tris, $100 \mathrm{mM}$ $1 \%$ N-Lauroylsarcosine, $\mathrm{pH} 10$ with Triton X-100 and $1 \% 10 \%$ DMSO) prepared freshly, remaining in solution for a period between 24 hours and two weeks at $4^{\circ} \mathrm{C}$. Each sample, was made in triplicate blades as a material reserve in case of problems in the making.

The slides were then allowed to stand in alkaline solution $(\mathrm{pH}>13)$ for 20 minutes and subjected to electrophoretic run at $25 \mathrm{~V}$ for $20 \mathrm{~min}$ at $300 \mathrm{~mA}$. Was used for each battery electrophoresis, a negative control and a positive control.

After electrophoresis, the slides were transferred to neutralizing solution (0.4 M Tris, $\mathrm{pH}$ 7.5) for 15 minutes, dehydrated in absolute ethanol for 5 minutes, stained with Syber Green (Sigma, St. Louis, MO, USA) and analyzed with a fluorescence microscope with filter 516 $560 \mathrm{~nm}$ and $590 \mathrm{~nm}$ barrier filter, coupled to image analysis system (Comet Assay II-Perspective Instruments, Haverhill, UK) Laboratory in the Center for Evaluation and Toxicogenetics Carcinogenic (TOXICAN) Department of Pathology, School of Medicine, UNESP Botucatu.

Have been analyzed 100 nucleoids and the parameter 
used to measure DNA damage was the tail intensity that represents the intensity of DNA and its percentage contained in the comet's tail.

To analyze the intensity of DNA damage in breast cells, the experiment was completely randomized with three groups and 22 repetitions. The group means were compared using the Tukey test. A comparison of the intensity of DNA damage in cells of breast carcinoma Bitches exposed and unexposed waste pyrethroid was made using the student $t$ test. We adopted the significance level $\mathrm{p} \leq 0.05$ [14].

\section{Results}

The intensity of DNA damage was higher in the cells of breast carcinoma bitches in relation to simple Bitches mammary cells that did not present in breast neoplasia ( $p$ $<0.05)$. Despite the differences were not significant ( $p>$ 0.05 ), the intensity of cell damage breast carcinoma Bitches complex was higher than the intensity of damage in the DNA of mammalian cells of dogs that did not have breast tumor. In different morphological types of cancers evaluated, the DNA damage was higher in dogs with simple carcinomas compared to dogs with complex metastatic breast, however, the differences were not significant $(\mathrm{p}>0.05)$ (Table 1).

Regarding the presence of breast pyrethroids in this study from 50 dogs, 44 did not show and 6 animals (12\%) had residues of one or more pyrethroids (Table 2). In adipose tissue, 40 animals did not show pyrethroids waste in this tissue and 10 animals (20\%) (Table 2) presented. Among the 12 dogs belonging to Groups I and II showed that residues pyrethroids, two residues were detected in both breast and in the adipose tissue.

By associating the 40 samples analyzed neoplastic (22 carcinomas and 18 simple complex carcinoma), independent of the tissue in which the residue was detected, there was no statistical difference $(p>0.05)$ when comparing the intensity of DNA damage between the 10 breast carcinoma cells exposed and the 30 breast carci-

Table 1. Mean and standard deviations (s) of the intensity of DNA damage in cells of breast carcinoma in female dogs that had single (Group I) complex carcinoma (Group II) and mammalian cells other than breast (Group III). Means followed by the same lowercase letters in the same column do not differ significantly by Tukey test $(p>0.05)$.

\begin{tabular}{ccc}
\hline \multirow{2}{*}{ Groups } & Intensity of DNA damage & $\mathbf{n}$ \\
\cline { 2 - 2 } & Mean $\pm \mathrm{s}$ & 22 \\
I & $11.63 \pm 8.31 \mathrm{a}$ & 18 \\
II & $8.02 \pm 4.19 \mathrm{ab}$ & 10 \\
III & $5.96 \pm 1.47 \mathrm{~b}$ & \\
& $\mathbf{p}=\mathbf{0 . 0 4}$ \\
\hline
\end{tabular}

Table 2. Frequencies residue of pyrethroids in breast carcinomas (Groups I and II) in normal breast (Group III) and adipose tissue adjacent to breast carcinomas (Groups I and II) and normal breast (Group III) bitches. Means followed by the same lowercase letters in the same column do not differ significantly by student's t test $(p>0.05)$.

\begin{tabular}{|c|c|c|c|c|}
\hline \multirow{3}{*}{ Groups } & \multicolumn{4}{|c|}{ Waste pyrethroids } \\
\hline & \multicolumn{2}{|c|}{ Mamma } & \multicolumn{2}{|c|}{ Tissueadipose } \\
\hline & Absence & Presence & Absence & Presence \\
\hline I & 21 & 1 & 17 & 5 \\
\hline II & 14 & 4 & 16 & 2 \\
\hline III & 9 & 1 & 7 & 3 \\
\hline Sub total & 44 & 6 & 40 & 10 \\
\hline Total & \multicolumn{2}{|c|}{50} & \multicolumn{2}{|c|}{50} \\
\hline
\end{tabular}

noma cells not exposed to pyrethroids (Table 3).

The marking cells of breast carcinoma of female dogs study by $\operatorname{Re} \alpha$ (Figure 1) and p63 (Figure 2) showed the usual pattern of nuclear staining, while marking the HER2 antibody was cytoplasmic (Figure 3). When Comet assay, cells from neoplastic and non-neoplastic breast citoaspirated and trypsinized acquired the expected appearance of a comet, with a head and tail, whose length varied with the intensity of DNA damage (Figure 4).

\section{Discussion}

The Comet assay involves running single cell gel electrophoresis, this method is very sensitive and reliable for detecting breaks in DNA strands or index of the DNA damage or intensity of migration of the DNA $[13,15]$. With the Comet assay applied to breast cells Bitches this study, we observed the intensity of DNA damage in these cells.

Although not statistical difference when comparing the intensity of damage in the DNA of neoplastic mammary cells with the histological profile of breast carcinomas Bitches this experiment, the tail intensity values found in the cells of breast carcinoma bitches in relation to simple Bitches breast cell carcinoma with complex and these in relation to breast Bitches who did not have breast malignancy, showed some correlation.

Based on the differences, although not significant, it could be said that the intensity of migration in the DNA of breast cells showed an increasing pattern of non-neoplastic breast for breast carcinoma and complex for those with breast carcinoma simple. This behavior might suggest that the more aggressive breast cancer greater damage cellular DNA as simple carcinoma is considered more aggressive than carcinoma complex, considering that is the malignant epithelial component of these tumors responsible for local and systemic progression of 
Table 3. Means and their standard deviations (s) of the intensity of DNA damage in cells of breast carcinoma in female dogs exposed and not exposed to pyrethroids. Means followed by the same lowercase letters in the same column do not differ significantly by student's $t$ test $(p>0.05)$.

\begin{tabular}{ccc}
\hline Pyrethroid & Intensity of DNA damage & n \\
\cline { 2 - 2 } & Mean $\pm \mathrm{s}$ & \\
\hline Cells unexposed & $10.83 \pm 5.17 \mathrm{a}$ & 30 \\
Cells exposed & $10.21 \pm 4.83 \mathrm{a}$ & 10 \\
$\mathbf{p}=\mathbf{0 . 7 4}$ & & \\
\hline
\end{tabular}

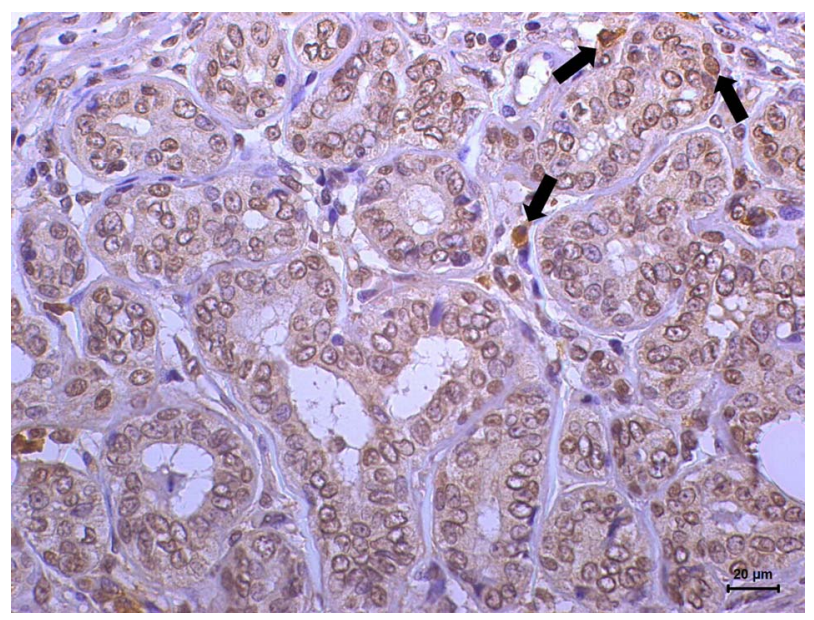

Figure 1. Immunoexpression of estrogen receptor- $\alpha$ in breast carcinoma of bitch. Nuclear staining in neoplastic cells (immunoreactivity in more than $10 \%$ neoplastic cells). (DAB, Novolink, counterstaining with Harris hematoxylin).

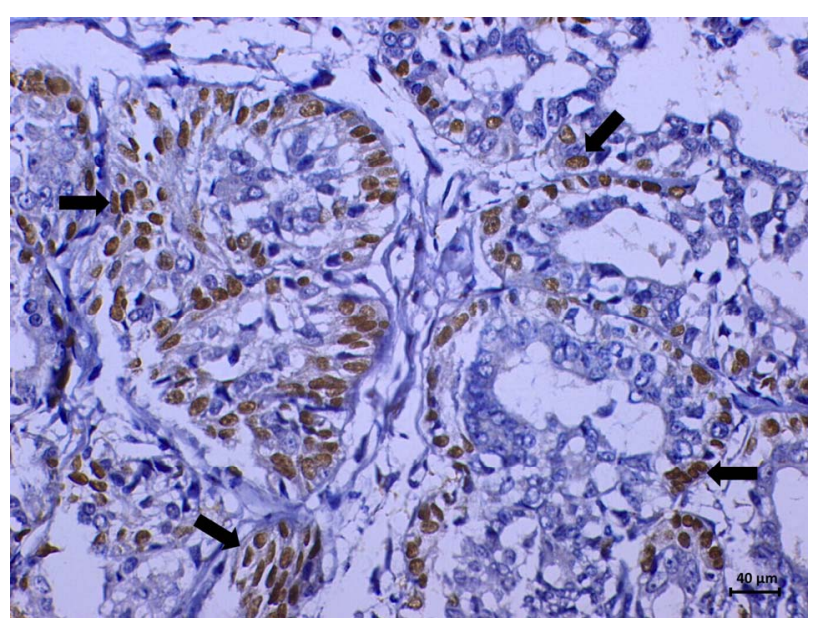

Figure 2. Immunoexpression of p63 in breast carcinomas of female dogs. Positive nuclear staining in neoplastic cells. (DAB, Novolink, counterstaining with Harris hematoxylin).

disease and that the prevalence is more simple carcinoma metastatic carcinoma of the complex [16].

However, it is important to note that differences in the intensity of DNA damage Bitches carcinomas of the two

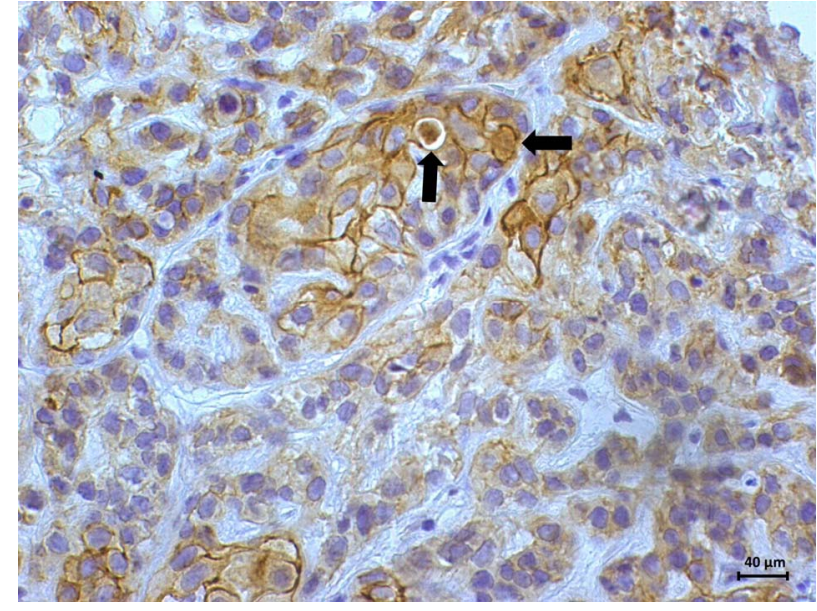

Figure 3. Immunostaining of HER-2 in breast carcinomas on female dogs. Marking positive $3+$ (strongly positive); complete marking membrane. (DAB, Novolink, counterstaining with Harris hematoxylin).

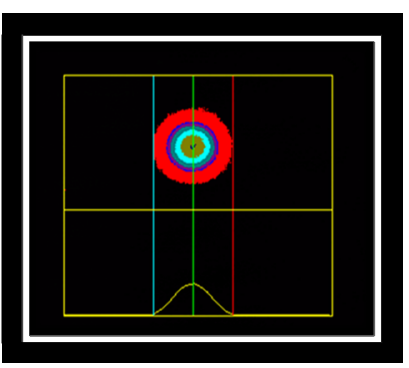

(a)

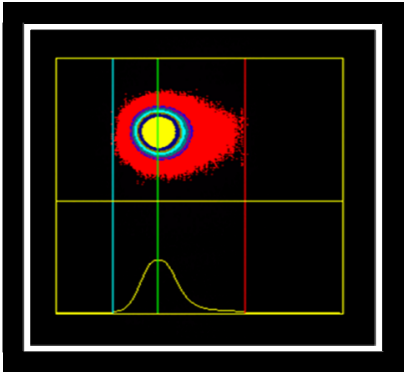

(c)

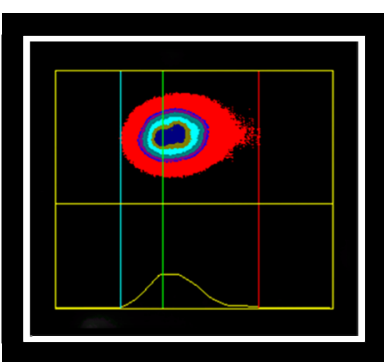

(b)

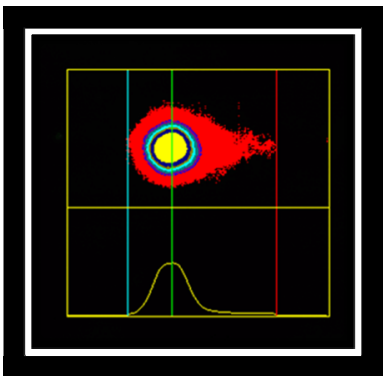

(d)
Figure 4. Photomicrographs of breast cancer cells in dogs subjected to comet assay. Extent of migration of the DNA (tail). (a) No tail, and tail with different sizes (b), (c), (d). Syber green fluorescencemicroscopy, 40×.

groups were not significant. From this fact, disregarded the division of the groups according to the histological classification of mammary tumors and was rated the intensity of the damage these cells could have been influenced by exposure to pyrethroid insecticides. It was observed that the DNA damage was not related pyrethroids, given that the intensity of damage between the neoplastic cells exposed and unexposed pyrethroids were similar. Thus one might think that pyrethroids were not part of 
carcinogenesis by genotoxic mechanisms [8-10], but probably not by genotoxic mechanisms.

However, the results obtained in this study relate to few cell samples. Obviously, further research involving larger samples and different methodologies, must be sustained in order to clarify whether the intensity of genomic injury may influence the biological behavior and hence the prognosis of breast carcinomas Bitches and if indeed pyrethroids are not genotoxic.

\section{Conclusion}

Under the experimental conditions and sample selected for the present study, it was concluded that the intensity of damage in the DNA of cells of breast carcinoma of the female dogs with less aggressive intensity is similar to DNA damage cell carcinoma aggressiveness with intermediate and highly aggressive carcinoma and damage are not related to exposure of the cells of these carcinomas waste allethrin, cypermethrin, deltamethrin and tetramethrin.

\section{REFERENCES}

[1] C. H. P. Burini, E. P. Bandarra, F. H. E. Andrade, N. S. Rocha, R. F. E. Lot, A. P. B. Masseno, G. B. Croce, B. B. A. Batista and M. S. Lagos, "Aspectos Epidemiológicos de Neoplasia Mamária em Cães," In: 9 Mostra Científica, Botucatu, Unesp, 2006.

[2] G. D. Cassali, "Otimização dos Métodos Para Avaliar o DNA Mitocondrial Obtido a Partir de Tumores Mamários Caninos Incluídos em Parafina," Jornal Brasileiro de Patologia e Medicina Laboratorial, Vol. 44, No. 1, 2008, pp. 305-308.

[3] F. H. E. Andrade, F. C. Fiqueiroa, P. R. O. Bersano, D. Z. Bissacot and N. S. Rocha, "Malignantmammary Tumor in Femaledogs: Environmental Contaminants," Diagnostic Pathology, Vol. 30, 2010, pp. 5-45.

[4] A. Demicco, K. R. Cooper, J. R. Richardson and L. A. White, "Developmental Neurotoxicity of Pyrethroid Insecticides in Zebrafish Embryos," Toxicological Sciences, Vol. 113, No. 1, 2010, pp. 177-186.

[5] L. Larini, "Toxicologia dos Praguicidas," Manole, São Paulo, 2000.

[6] D. M. Soderlund, J. M. Clark, L. P. Sheets, L. S. Mullin, V. J. Piccirillo, D. Sargent, J. T. Stevens and M. L. Weiner, "Mechanisms of Pyrethroid Neurotoxicity: Implications for Cumulative Risk Assessment," Toxicology, Vol. 171, No. 1, 2002, pp. 3-59.
[7] International Agency for Research Cancer, "IARC: Overall Evaluations of Carcinogenicity to Humans," International Agency for Research Cancer, Lyon, 1987.

http://monographs.iarc.fr/ENG/Monographs/vol53/mono5 3-10.pdf

[8] R. Gabbianelli, M. L. Falcioni, F. Cantalamessa and C. Nasuti, "Permethrin Induces Lymphocyte DNA Lesions at both Endo III and Fpg Sites and Changes in Monocyte Respiratory Burst in Rats," Journal of Applied Toxicology, Vol. 29, No. 4, 2009, pp. 317-322. doi:10.1002/jat.1412

[9] R. Gabbianelli, C. Nasuti, G. Falcioni and F. Cantalamessa, "Lymphocyte DNA Damage in Rats Exposed to Pyrethroids: Effect of Supplementation with Vitamins E and C," Toxicology, Vol. 203, No. 1-3, 2004, pp. 17-26. doi:10.1016/j.tox.2004.05.012

[10] M. Tisch, P. Schmezer, M. Faulde, A. Groh and H. Maier, "Genotoxicity Studies on Permethrin, DEET and Diazinon in Primary Human Mucosal Cells," European Archives of Otorhinolaryngology, Vol. 259, No. 3, 2002, pp. 150-153. doi:10.1007/s004050100406

[11] L. K. Chauhan, "Cytogenetic Effects of Commercial Formulations of Deltamethrin and/or Isoproturon on Human Peripheral Lymphocytes and Mouse Bone Marrow Cells," Environmental and Molecular Mutagenesis, Vol. 48, No. 8, 2007, pp. 636-646. doi:10.1002/em.20330

[12] D. Z. Bissacot and I. Vassilieff, "HPLC Determination of Flumethrin, Deltamethrin, Cypermethrin, and cyhalothrin Residues in Milk and Blood of Lactating Dairy Cows," Journal of Analytical Toxicology, Vol. 21, No. 5, 1997, pp. 397-402. doi:10.1093/jat/21.5.397

[13] N. P. Singh, M. T. McCoy, R. R. Tice and E. L. Schneider, "A Simple Technique for Quantitation of Low Levels of DNA Damage in Individual Cells," Experimental Cell Research, Vol. 175, No. 1, 1988, pp. 184-191. doi:10.1016/0014-4827(88)90265-0

[14] G. W. Snedecor and W. G. Cochran, "Statistical methods," 8th Edition, Iowa State University Press, Ames, 1994.

[15] S. Colleu-Durel, N. Guitton, K. Nourgalieva, F. Legue, J. Leveque, B. Danic and C. Chenal, "Alkaline Single-Cell Gel Electrophoresis (Comet Assay): A Simple Technique to Show Genomic Instability in Sporadic Breast Cancer," European Journal of Cancer, Vol. 40, No. 3, 2004, pp. 445-451. doi:10.1016/j.ejca.2003.09.033

[16] M. F. Cavalcanti and G. D. Cassali, "Fatores Prognósticos no Diagnóstico Clínico e Histopatológico dos Tumores de Mama em Cadelas-Revisão," Revista Clínica Veterinária, No. 61, 2006, pp. 56-63. 